\title{
Review of Ethnopharmacology, Morpho-Anatomy, Biological Evaluation and Chemical Composition of Syzygium polyanthum (Wight) Walp.
}

\author{
Mahmoud Dogara Abdulrahman \\ Department of Biology, Faculty of Education, Tishk International University-Erbil, Kurdistan Region, Iraq
}

^Email: abdulrahman.mahmud@tiu.edu.iq

OPEN ACCESS

\section{ARTICLE HISTORY}

Received: 17 June 2021

Accepted: 23 October 2021

Available online

Version 1.0 (Early Access): 25 December 2021 Version 2.0:01 January 2022

\section{Check for updates}

\section{Additional information}

Peer review: Publisher thanks Sectional Editor and the other anonymous reviewers for their contribution to the peer review of this work.

Reprints \& permissions information is available at https://horizonepublishing.com/ journals/index.php/PST/open_access_policy

Publisher's Note: Horizon e-Publishing Group remains neutral with regard to jurisdictional claims in published maps and institutional affiliations.

Indexing: Plant Science Today, published by Horizon e-Publishing Group, is covered by Scopus, Web of Science, BIOSIS Previews, Clarivate Analytics, etc. See https:// horizonepublishing.com/journals/index.php/ PST/indexing_abstracting

Copyright: $(\subset)$ The Author(s). This is an openaccess article distributed under the terms of the Creative Commons Attribution License, which permits unrestricted use, distribution and reproduction in any medium, provided the original author and source are credited (https://creativecommons.org/licenses/ by/4.0/)

\section{CITE THIS ARTICLE}

Abdulrahman M D. Review of Ethnopharmacology, Morpho-Anatomy, Biological Evaluation and Chemical Composition of Syzygium polyanthum (Wight) Walp. Plant Science Today . 2022;9(1):167-177. https:// doi.org/10.14719/pst.1386

\begin{abstract}
Syzygium polyanthum (Wight) Walp., a Myrtaceae member, is widely distributed in Southeast Asian countries. The Malays and Indonesians consume the leaves regularly as Ulam (food). It has also been used in traditional medicine to treat several ailments, including gastritis, hypertension, hypercholesterolemia, diarrhea, skin diseases, diabetes and endometriosis. So far, many publications on the biological activity and chemical profile of the plant have been published. There is a need to thoroughly examine the articles and combine the major findings highlighting the potential utility of the species. Thus, the present study aimed to review the ethnopharmacology, morpho-anatomy, biological evaluation and chemical composition of $S$. polyanthum. In vivo, in vitro antibacterial, antimicrobial, antidiabetic, antioxidants, essential oil and chemical composition of S. polyanthum were searched in Google Scholar, Scopus, Web of Science and PubMed. The investigations revealed that $S$. polyanthum is a medicinal plant with proven antioxidant, antibacterial, antifungal, antidiabetic and anti inflammatory activities. The plant had a substantial impact on human health. Chemical ingredients extracted and characterised are monoterpene, sesquiterpene, oxygenated monoterpenes, oxygenated sesquiterpenes, phenolic and flavonoid compounds. The review found that the in vitro and in vivo biological evaluation of S. polyanthum was well documented. In order to have conclusive results on the plant leaves efficacy, a well-designed clinical trial is required. Efforts should also be taken for long-term conservation and management.
\end{abstract}

\section{Keywords \\ Syzygium polyanthum, phytopharmacology, phytochemistry, traditional uses}

\section{Introduction}

Since times, man has been utilising plants as the source of food and health care system to himself and his domesticated animals, it also serves as the source that provides readily available oxygen (1). Certainly, the great civilizations of the ancient Chinese, Indians and North Africans provide written evidence of man's ingenuity in utilizing plants for the treatment of a wide variety of ailments (2). To satisfy the curiosity and willingness in understanding the way environment and plants are interacting to help man survive, the field of ethnobotany is becoming pronounced globally $(3,4)$.

Many countries have adopted plants as the major source of their medical care due to the large costly price of modern medicine $(1,3)$. The accessibility and low-cost of the medicinal traditional system are two main 
ideas that drive man reliance on plant (5). In this line, World Health Organisation (WHO) in 2013 documented that about $80 \%$ of the world population largely depend on the traditional medicinal system to treat their various ailments and improve their health status (4). It is estimated that $70-80 \%$ of people worldwide rely on traditional herbal medicine to meet primary health care needs and it is also used for income generation for livelihood improvement (6, 7).

There are approximately 250000 species of plants available globally, however, only $1 \%$ of tropical species have been studied for their medicinal properties (8). This contemporary world makes people more conscious of their well-being; people are now looking for a plant-based product to replace the expensive and synthetic products available all over the market (9). The demand for the product from plants source as a natural product will continue to increase because of their ability to cure and improve health status $(10,11)$. Traditional herbal medicine is given much attention when people begin to notice and observed the long-term effects of modern drugs. Studies have been conducted and documented to determine the efficiency of the traditional medicinal plants $(12,13)$. This study aimed to review the ethnopharmacology, morpho-anatomy, biological evaluation and chemical composition of S. polyanthum (Wight) Walp.

\section{Ethnopharmacology}

Syzygium polyanthum is utilized for therapeutic purposes for a long time. Medically, the usage of plant parts has been developed as an alternative medical plant (14). S. polyanthum is among the preferred Ulam that has been taking for ages and is widely distributed all over Asian countries $(1,9,15)$.

Syzygium polyanthum is locally called Serai kayu, Serai kayu hutan, Daun salam and many more other names among the people in Malaysia $(16,17)$. Whilst in Indonesia, it is named as Indonesian laurel or Bay leaf. In Indonesia it is one of the most popular medicinal plants with therapeutic value $(18,19)$. Mak, Doc maeo and Daeng klua are the Thai names, while San thuyen is the Vietnamese name (20). Parts of these plants are used to treat a variety of ailments around the world, particularly in Asia, Malaysia and Indonesia. These ailments include diabetes, high blood pressure, postpartum, cough, fever, vaginal infection, respiratory ailments, gastrointestinal, cancer and microbial diseases. Hypertension, diarrhea, diabetes and endometriosis have also been claimed to be cured $(9,17)$. South-East Asian cuisine is frequently flavored with this herb to give them a fresh, fragrant flavor (21). Its fruits and roots extracts can alleviate the effects of excessive alcohol intake (14). In Indonesia, the leaf is traditionally used to treat cardiovascular problems (22).

An ethnobotanical study conducted among diabetic outpatients at Health Community Centre in Medan, Indonesia, found S. polyanthum the most often used medicinal plant as traditional therapy for diabetes mellitus (23). It has long been used to treat a variety of ailments, the most well known of which being hypertension and diabetes (24,
25). As a traditional Malay remedy for hypertension, the leaves are ingested (15).

The leaves of S. polyanthum are well-known as a traditional remedy for diarrhea, cataracts, hypercholesterolemia, gastritis, skin problems and diabetes mellitus (14). Gastritis, diarrhea, itching, diabetic mellitus, astringent and scabies can all be treated using leaf extract (26). For diarrhea, a mixture of bark and leaves is used, while a mixture of leaves, bark and roots is crushed to provide relief from itching (27). Its leaves, bark, stem and roots are all used to treat diarrhea, diabetes and high blood pressure (28). Antidotes for alcohol intoxication include a blend of fruits and roots (27). It's also used to treat patients who have elevated uric acid levels (26). The leaves are mildly astringent or sour and when frying, the flavor intensifies (28). When the leaf is squeezed, it emits a pleasant scent (29). The leaf can be used as a seasoning, while the bark can be used to colour nets and woven bamboo (29). Its wood is used to make houses, furniture, tan fishing nets and colour bamboo matting brown-red (27).

Decoction and infusion are the most commonly used method to prepare the Syzygium plant parts; especially their leaves, bark and roots (9). In Malaysia, the plant parts of these plants are widely used in cooking as a result of scent color, flavor and odor (30-32). It is frequently used as flavor or spices for the dishes like vegetables, fish, meat, rice and many other types of food (33). Because of its strong aroma, it's commonly used as a spice in Indonesia (34). This plant plays an important role in the preparation of one of the favourites meals in Malaysia called 'nasi kerabu' and 'kerabu perut' or consumed raw leaves as 'Ulam' (16).

\section{Taxonomic History of Myrtaceae}

Myrtaceae is a pantropical family of trees and shrubs with nearly about 55000 species, classified into two subfamilies, 17 tribes and 142 genera (35). They are mainly found in a large number in Central America, South America, Australia and the southern hemisphere (36). In Southeast Asian countries, they are widely disseminated and farmed (37).

Generally, the leaves of the Myrtaceae are in the opposite direction, internal phloem, evergreen and woody and abundance of oil glands in most of the members (38). The members are bisexual with polystemonous, fully inferior or partial inferior ovaries mostly with nectariferous hypanthium and actinomorphic flower (36). The monophyletic tribe Myrteae comprises most of the fleshy fruited Myrtaceae (39).

\section{Evolution and Ecological Distribution}

The genus Syzygium Gaertn. Comprises of many species within the genus (40). Syzygium is the largest genus in the family of Myrtaceae, having approximately one thousand two hundred (1200) species (41). At the same time, it has been documented as the major (largest) genera of flowering plants (42). The genus was known for the ability to withstand drought which lead to their successful abundance. Syzygium species can be found in a wide range of environments (27). 
History has shown that these species originated from South Asia countries like Nepal, Sri Lanka, Pakistan and India $(38,43)$. Though they are distributed all over the world, they are mostly found in tropical and subtropical regions (43). In terms of species richness, the genus is centered in Southeast Asia (44). This plant can be found in Thailand, Myanmar, Indo-China, Malaysia and Indonesia among other places (24).

From Malaysia to northeastern Australia, it has the most variety with numerous species that are poorly known and many more that have yet to be taxonomically defined (43). But for decades, the species Syzygium has been naturalized in Malaysia and became more successfully adapted to the environment (45). Members of this genus are reported to be rich in medicinally valuable volatile oils (46). Because of the extensive therapeutic potential, it has been widely disseminated (38).

Malaysia, Thailand, Indonesia and Singapore are among the Southeast Asian countries where S. polyanthum can be found. S. polyanthum is synonymous with S. microbotryum, S. micranthum, S. cymosum, Myrtus cymosa, Eugenia resinosa, E. polyantha, E. nitida, E. polyantha, E. pamatensis, E. microbotrya, E. lucidula, E. junghuhniana, E. lambii, E. holmanii and E. atropunctata. Indian Baywatch, Bay leaf and Japanese Baywatch are some of the common names for this species. The plant can be found in forests, streams, humid rainforests or waterlogged environments and hilly areas (38).

\section{Morphology}

Syzygium polyanthum consists of densely foliaceous and large evergreen plants with thick bark and grayish brown wood (Fig. 1A). S. polyanthum has a taproot and a circular trunk with a slick surface (29). They have leathery leaves that are 6-12 cm long and shaped obovate elliptic or oblong ovate (Fig. 1B and C) (3). The leaves have a wide range of shapes, primary, secondary and tertiary veins are shiny and smooth and the tips are less acuminate and broad $(47,48)$. Panicles, which are 4-6 cm long and terminal or axillary, emerge from the branchlets beneath the leaves (Fig. 1B).

The flower from S. polyanthum is in a cluster of oblong or round shapes, yellowish white and scented (Fig. 1E). The calyx is about $4 \mathrm{~mm}$ long with a funnel shape and toothed (49). The petals look like a small disk, numerous stamens of about $4 \mathrm{~mm}$ long, but of different size and colour based on the species and environmental factor (49).

Fruits are oblong, ranging from $0.5-3.5 \mathrm{~cm}$ long, which are black or dark purple, the bear seed within the fruits (Fig. 1D). Lateral nerves $6-11$ pairs, not tightly parallel; elliptic leaves to lanceolate with slightly citrus odor and mildly sour taste are summarized as the morphological key for identification (50).

\section{Anatomy}

The leaf lamina transverse section revealed the presence of three layers of palisade mesophyll filling $2 / 3$ part leaf lamina at adaxial part with four to five layers of spongy mesophyll (Fig. 2A) (35). Large intracellular space at the abaxial part (Fig. 2A). Oil glands were present at the adaxial part at

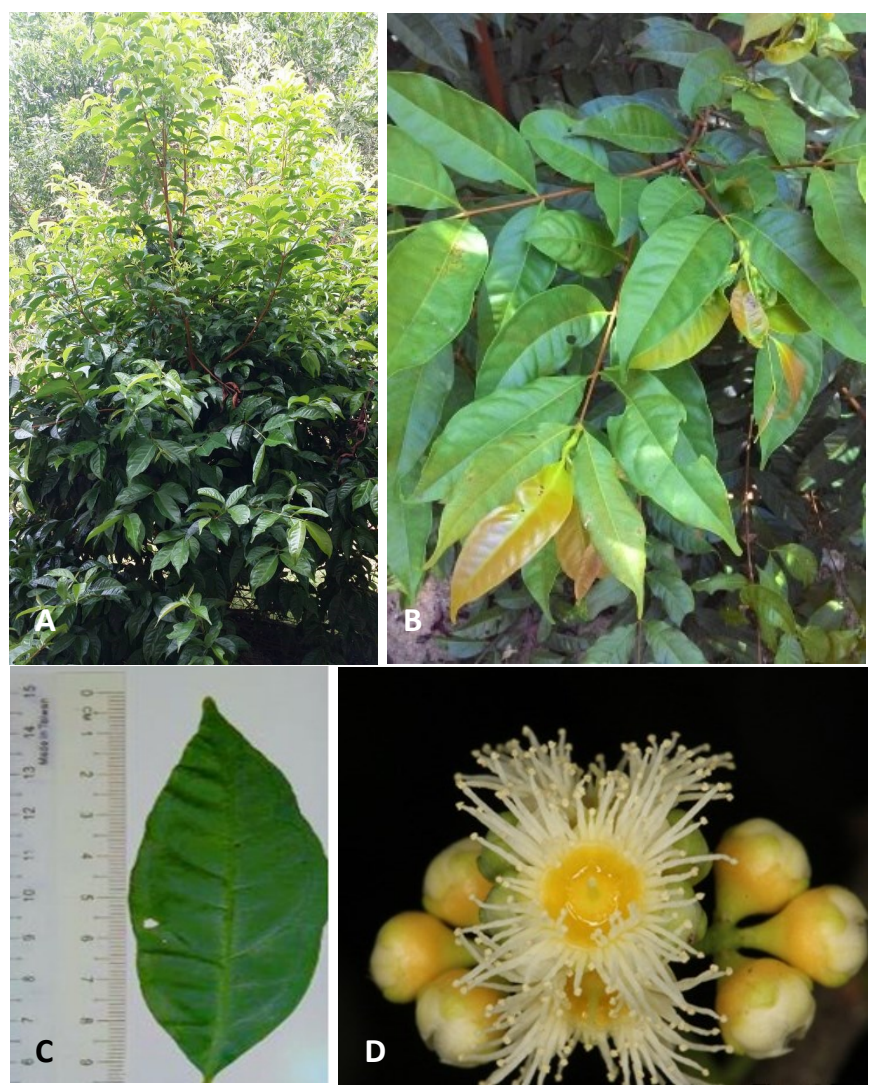

Fig. 1. Syzygium polyanthum whole plant (A), branch (B), leaf (C), Seed and flower (D) (116).

about $1 / 3$ of the lamina transverse section (35). Anisocytic stomata; three non-radially arranged cells surround the guard cells (51). The subsidiary cells are mostly unequal in size, with one of the three being smaller than the other two [34].

The average stomatal length and width was 7-24 and $3-12 \mu \mathrm{m}$ respectively (35). Hypo stomatic stomata. A simple trichome was seen in the abaxial part of the lamina transverse (35). The vascular system at the midrib cross section was found an open system of vascular tissue, $3 / 4$ or circular shape with an opening at the adaxial side $(35,50,51) .3 / 4$ of the petiole was occupied by parenchyma cells. Small oil glands were seen all over the petiole transverse section (Fig. 2A) (35).

Petiole anatomy have diagnostic taxonomical value for specie identification and later distinguished petiole vascular system as opened and closed system respectively (35). The vascular system at the petiole transverse section was found to be circle or oval shape vascular tissue, flat at adaxial surface and complete circle at the abaxial surface, sclerenchyma ensheathing the vascular tissue, follows by seven to eight layers parenchyma cells and small oil gland was seen all over the abaxial part. The over roll petiole transverse section is a circle shape at the abaxial surface and $U$ shaped at the adaxial surface (Fig. 2B) (35).

Vascular system in the stem are significant importance for taxonomic identification of Myrtaceae family. Stem cross section were found to have closed vascular system. Vascular tissue is a circle form with no definite shape. Parenchyma pith was seen at the center of the vascular tissue. Sclerenchyma cells ensheathing the vascular tissue. 1/4 of the cross section of the stem was filled with parenchyma 
cells. $3 / 4$ of the stem cross section is circle at the adaxial surface and $1 / 4$ at the abaxial surface is flat (Fig. 2C).
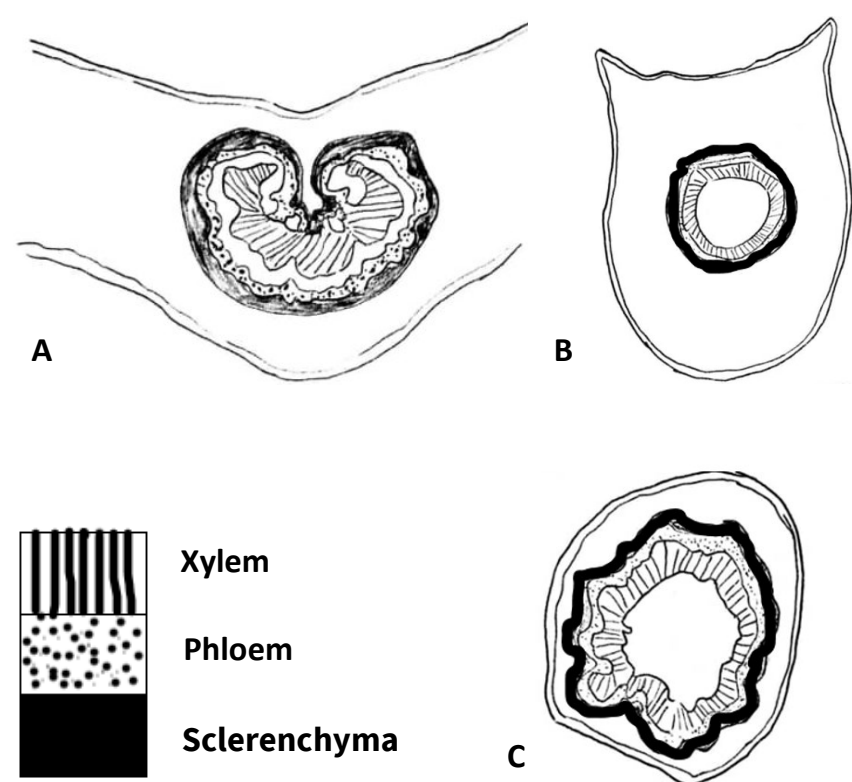

Xylem

\section{Phloem}

\section{Sclerenchyma}

Fig. 2. Vascular bundle from the midrib (A), petiole (B) and stem (C) of S. poly anthum respectively.

\section{Biological Evaluation}

Numerous studies on the biological evaluation of S. polyanthum parts (leaves, bark, stem, root) were conducted to investigate its biological activity against free radicals, bacterial, fungi or enzymes that cause diabetes (Supplementary Table 1). When compared to the other sections of the plant, leaves are determined to have the most biological activity (Supplementary Table 1).

Secondary metabolites were thought to be the most therapeutic component of the plant and they are largely produced in the leaves (16). A wide range of polarity, from non-polar to polar, should be used to extract the component from the plant parts (52). Extraction using different polarity solvents would be more successful in releasing the chemicals and obtaining extracts with semi-overlapping components (52). As can be seen in Supplementary Table 1, the biological potential of S. polyanthum was investigated using a variety of solvents.

\section{Antioxidants}

Secondary metabolites come in a variety of shapes and functions, depending on the plant and its sections (38). Many nutritional supplements, nutraceuticals and functional food additives contain antioxidants, which help to preserve food by blocking oxidation processes and contribute to health promotion (53). Free radicals in the form of reactive nitrogen and oxygen species cause oxidative damage to nucleic acids, lipids and proteins. As a result, human chronic diseases such as aging, cancer and atherosclerosis may develop (21). A range of assays with diverse methods can be used to measure antioxidant activity (54). DPPH, FRAP and the Bleaching assays were among the methods employed to assess the antioxidant capacity of the oils and crude extract Supplementary Table 2.
S. polyanthum essential oil and crude extracts were discovered to protect against oxidative damage by blocking or quenching free radicals (Supplementary Table 2). Both extracts (Ethyl acetate and methanolic) have good antioxidants properties at $\mathrm{IC}_{50}$ of 13 and $21 \mu \mathrm{g} / \mathrm{ml}$ respectively (55). The aqueous extract has an inhibition percentage of $84.83 \%$, which is quite high (21). Leaves of S. polyanthum are known to contain active phenolic chemicals, which have antioxidant properties (21). They have been demonstrated to be effective as synthetic antioxidant replacements.

\section{Antidiabetic}

Because of its great incidence and characteristics that might lead to other diseases, diabetes mellitus is a degenerative disease that receives a lot of attention when it comes to treatment (58). Diabetes currently affects 463 million people globally, with that number anticipated to increase to 578 million by 2030 (58). The antidiabetic investigation on the leaf revealed it to be promising against the diseases (24). Linalool, a recognized chemical with antidiabetic properties was found in the leaves (59). The presence of coumarins, flavonoids, terpenoids and polyphenols in the plant has been linked to their anti-diabetic properties (24).

Leaf has an antihyperglycemic action, lowering blood sugar levels from $5.9 \pm 0.11 \mathrm{mmol} / \mathrm{L}$ to $3.4 \pm 0.05$ $\mathrm{mmol} / \mathrm{L}$ respectively (24). The Butanol portion of S. polyanthum inhibited alpha glucosidase potently, as demonstrated by a low $\mathrm{IC}_{50}$ of $28 \mathrm{~g} / \mathrm{ml}$ (59) and has $41.4 \%$ antidiabetic inhibition a-glucosidase activity (29). At $500 \mathrm{~g} / \mathrm{ml}$, the fraction's ability to inhibit -glucosidase from acetone-water was at its peak, with a $97.34 \%$ inhibition rate (4:1) (57). The leaf extract has the potential to be used in the development of a functional drink to reduce diabetes risk (29). The diabetic volunteers in this study had high BGL levels, indicating that their diabetes was uncontrolled. The FBGL was reduced to $8.85 \%$ after 14 days of administration of the capsule (61). Leaf extracts given at a dose of $5.0 \mathrm{mg} / \mathrm{kg}$ body weight/day show an anti-diabetic effect (62). The ethanolic leaf exhibited IC $\mathrm{C}_{50}$ of Alpha Glucosidase at 19.06 and Alpha Amylase at $90.24 \pm 1.43 \mu \mathrm{g} / \mathrm{ml}$ respectively (63). The ethanolic leaves extract of S. polyanthum was found to be an efficient anti-hypoglycaemic agent, with an optimal dose of 5.0 mg kg-1 (64). Its leaves included essential oils, flavonoids, tannins, terpenoids and fatty acids, according to the phytochemical analysis (24). As a result, the existence of the aforementioned compound is related to the antidiabetic properties of the plant.

\section{Antibacterial}

Due to their unrivalled chemical variety, natural chemicals in plant extracts or pure compounds can provide limitless potential for pharmacological therapy (25). There is an ongoing and urgent need to discover new antimicrobial compounds with diverse chemical structures and novel mechanisms of action due to an alarming increase in the incidence of new and re-emerging infectious diseases, as well as the development of resistance to antibiotics currently in clinical use. There are several methods for detecting anti- 
bacterial activity currently available and the findings obtained vary because they are not all based on the same principles (Supplementary Table 1). The variations in the results could be due to the type of solvents utilized (Supplementary Table 1). The extracts from S. polyanthum leaves may be effective in the treatment of diaper rash, vaginal yeast infection, skin and other Candida infectionrelated disorders (18).

The use of essential oils as an antibacterial agent is becoming more popular, owing to its natural origin, broad spectrum of activity and generally recognized as safe status (23). Several bacterial were examined using various methods, including disc, agar and well diffusion method respectively Supplementary Table 2. Bacillus subtilis growth was substantially inhibited, while Salmonella typhimurium, Staphylococcus aureus and Vibrio cholera growth were marginally inhibited (65). Their main chemical ingredients, aldehydes and eugenol were involved in these antimicrobial activities (65). Methanolic and $n$-hexane extracts have $I C_{50}$ values of 23.16 and 35.01 and 49.25 and 27.54 at $\mu \mathrm{g} / \mathrm{ml}$ respectively against $S$. aureus and E. coli (25). There was no activity on the gram negatives examined, but there was significant activity on the gram positives Luteus and Mycobacterium smegmatis (20). The leaves extract has a lot of effectiveness against the microorganisms that cause food poisoning (66). Its antibacterial properties may make it suitable for using as a natural food preservative.

\section{Antifungal}

With the rising frequency of outbreaks of food-borne illnesses, food contamination has become a major concern (67). Plant bioactive plant extracts are widely used as medicine all over the world (67). All of the extracts are effective against Mucor hialisalis (20). Fusarium oxysporum growth is significantly slowed (69). At $500 \mu \mathrm{g} / \mathrm{ml}$ Candida tropicalis, Aspergillus flavin, Fusarium oxysporum and Aspergillus niger showed significant growth suppression (68). This plant has antifungal properties against food spoilage fungi Aspergillus spp., Euroticum spp. and Penicillium spp. (70). These findings support the use of plant essential oils to keep bread fresh without the use of chemicals (70). The extract's antifungal activity increased significantly as concentrations were increased (71).

\section{Antihypertensive}

Hypertension is a life-threatening condition. The \% of people with a systolic blood pressure of $140 \mathrm{mmHg}$ or higher grew from $17.31 \%$ in 1990 to $20.53 \%$ in 2015 (72). At mg/kg, aqueous (20-100) and methanolic (40-100) extracts significantly reduced their blood pressure (15). According to this study, both methanolic and aqueous extracts of $\mathrm{S}$. polyanthum leaves were able to cause significant vasorelaxation in normal and hypertensive rats (72). Acute ADSP (2.50 to $3.00 \mathrm{~g} / \mathrm{kg}$ ) and MESP (2.00 to $3.00 \mathrm{~g} / \mathrm{kg}$ ) treatment significantly lowered the hypertension (73). Have a reno protective effect in improving renal morphology in 22 hypertensive rats (74).

\section{Antidiarrhea}

Diarrhea is one of the primary causes of death among children under the age of five in developing countries, account- ing for $19 \%$ of all deaths among children under the age of five (75). The quest for antidiarrheal active extracts is critical to achieving diarrhea treatment. In animal models, a 30 $\%$ concentration of the extract shows effective antidiarrheal properties (75).

\section{Evaluation as Food Sanitizer}

Fresh fruits and vegetables might include a variety of germs that originated in the growing environment (76). If appropriate decontamination procedures are not taken, bacteria will continue to multiply throughout postharvest handling and food processing, resulting in food spoilage (76). In this study, the total plate count was drastically reduced after exposure to $0.50 \%$ for 5 min of soaking (66). There were no statistically significant differences in exposure times. In chicken and shrimp, 10 min of treatment with $1.0 \%$ extract resulted in the greatest reduction in the microbial population (67).

\section{Antitumour}

Plants are useful in medicine because they contain chemical components that have a physiological role in the human body (77). The early-antigen of Epstein-Barr virus, which was produced by a tumour promoter was fully repressed (78).

\section{Anticholesterol level}

Obesity is characterized by an imbalance in energy intake and expenditure, resulting in the fat build up in the body. Natural products offer a wealth of possible components for use as an anti obesity treatment (79). Anticarcinogenic, anti oxidant, anti microbial and anti inflammatory effects have been discovered in hydroxychavicol. These findings imply that this herb could help with a range of health problems, including obesity (80). The extract inhibits pancreatic lipase activity by $43.14 .02 \%$ when used at $500 \mathrm{~g} / \mathrm{ml}$ (79).

\section{Antiinflammatory}

Inflammation manifests itself as pain, heat, redness, swelling and functional problems and is a common Défense response to tissue injury caused by physical trauma (81). The findings show that a dose of $75 \mathrm{mg} / \mathrm{kg}$ BW has the same effect as anti-inflammatory drugs in lowering edema volume in the rat foot (81).

\section{Antidental plaque}

Everyone's right to health, especially their oral health, is unalienable. Plaque build-up was successfully reduced (82).

\section{Anticardiovascular}

Cardiovascular disease (CVD) is becoming more common over the world. Each year, 17.9 million people die from cardiovascular disease, according to the World Health Organization (WHO) (82). The prevalence of cardiovascular disease was $48 \%$ in 2013-2016, according to the National Health and Nutrition Examination Survey and it tends to climb with age (83). Administration of CRP and MPO decreased CRP and MPO levels in rats starting on day 4 after induction of myocardial infarction (83). Downregulation of ADAM17, which controls TNF regulation, is most likely the mechanism (84). 


\section{Cytotoxicity evaluation}

Toxicity is defined as any substance that caused harmful effects in a long run or immediately to the human system, after multiple or single consumption of such constituents within the first one to $24 \mathrm{hrs}$ interval (85). The biological effect of the substance can be described as any changes or damages in an organ, or biochemical reaction that takes place within the body system of an organism. The leaves and fruit extracts of S. polyanthum were found to be inactive when tested using the brine shrimp lethality test (18). While in another study it demonstrated relatively little toxicity to brine shrimp larvae (LD50>1000g / ml) (29). The results showed that the concentration with higher is more poisonous with $\mathrm{LC}_{50}$ values of $707.945 \mu \mathrm{g} / \mathrm{ml}$ for a $70 \%$ ethanol extract and $977.237 \mu \mathrm{g} / \mathrm{ml}$ for a $96 \%$ ethanol extract both of which were non-toxic since $\mathrm{LC}_{50}$ is below $1000 \mu \mathrm{g} / \mathrm{ml}$ (85). Normal mammalian cell lines are unaffected by the leaves of S. polyanthum (15). With $\mathrm{IC}_{50}$ values ranging from $672.5759 \pm 42$ to $126.0550 \pm 89 \mu \mathrm{g} / \mathrm{ml}$, the extract has a low cytotoxicity effect (87). At an IC $\mathrm{C}_{50}$ of $18.42 \mu \mathrm{g} / \mathrm{ml}$, the extracts were confirmed to be non toxic (68).

\section{Chemical contents}

Many natural product chemists from throughout the world have been drawn to study physiologically active natural compounds derived from plants (18). Natural compounds with therapeutic characteristics are a valuable source of pharmacologically active molecules (110). Plant essential oils are highly volatile and have a distinct odour due to a complex blend of monoterpenes and sesquiterpenes (23).

The chemical makeup of essential oils of S. polyanthum has been researched on occasion by researchers from various parts of the world $(3,59,99)$. Because of the medicinal properties of S. polyanthum essential oil (EO), increased phytochemical research on these species has focused on the EO. Monoterpenoids, sesquiterpenoids and fatty alcohols make up the majority of the EO. Chemical substances extracted from essential oils of the plant S. polyanthum are<smiles>C=CCc1ccc(O)c(O)c1</smiles>

Hydroxychavicol

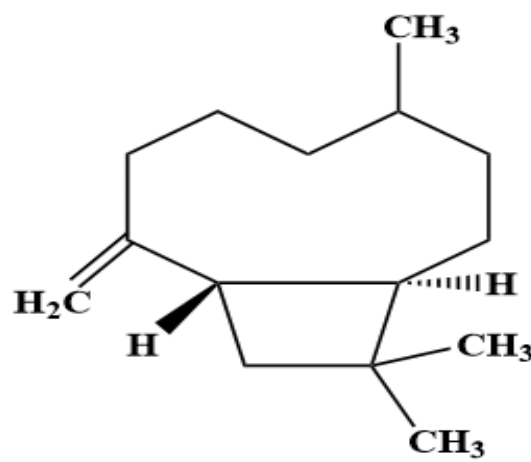

Caryophyllene

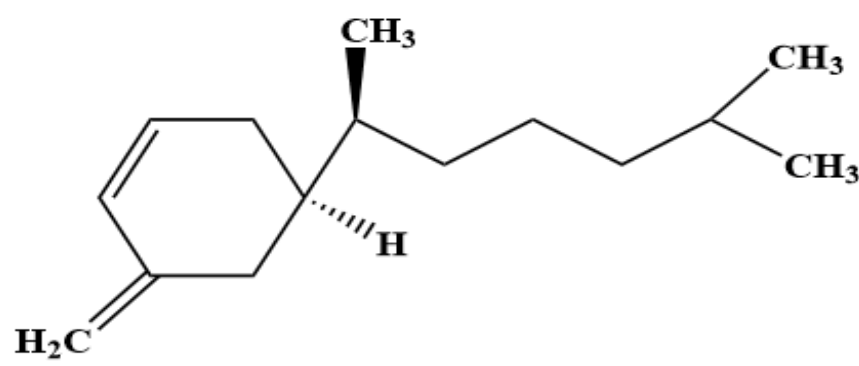<smiles>[AsH]</smiles>

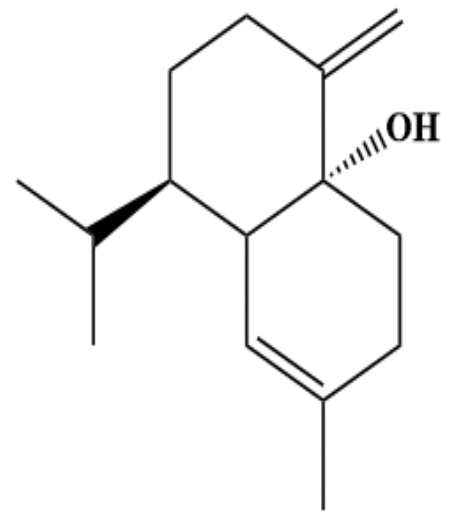

Geranial<smiles>c1ccc(C2CCC3CCCCC3O2)cc1</smiles>

Flavonoids

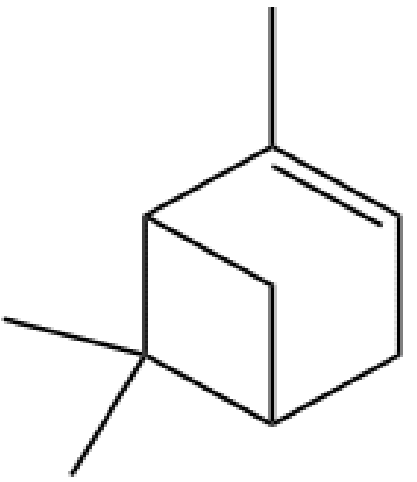

Alpha- Pinene
Muurola-4,10(14)-dien-1«beta»-ol

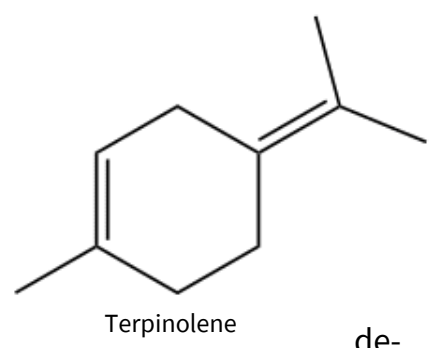

de-

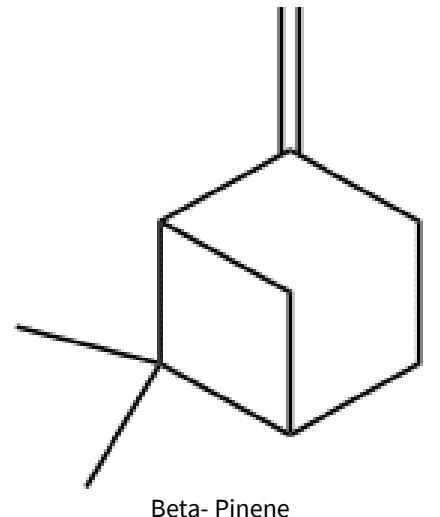

Beta- Pinen

Fig. 3. Some of the chemical structure identified from Syzygium polyanthum

scribed (Fig. 3). These family members are known to be high in volatile oil (43). Several studies on the chemical constituents of S. polyanthum were conducted (Supplementary Table 2). The plants are particularly scented as a result of their composition (3).

GC/MS was used in several investigations, primarily on the leaves (65). Monoterpenese and sesquiterpenes are abundant in the plant, according to reports (Supplementary Table 2). Monoterpenese account for 53.8 $\%$ of the volatile oil's identified compounds, while sesquiterpene accounts for $16.22 \%$ (3). Octanal (18. 30), alphapinene (30.88) and alpha-caryophyllene (6.22) \% are the major constituents (111), followed by 1-Decyl aldehyde (19.75), cis-4-decanal (43.489\%) and capryl aldehyde (14.09) \% (65).

Supplementary Table 2 also shows how the composition of essential oils from the S. polyanthum collected from different origins differ in terms of composition. This is due to the geographic origin, plant ontogeny and growing altitude of the plant habitat. The solvents used and the type of extraction used may also play a role in the difference in the chemical composition and its content. Squalene, for 
example, is the most abundant chemical in leaves gathered from S. polyanthum in Kelantan in 2016, whereas alphapinene is the most abundant compound in leaves obtained from Besut Terengganu in Malaysia $(3,59)$.

Environmental conditions have an impact on the oil yield and chemical composition (3). Essential oil is used to cure a variety of ailments, including infections, as well as an insect repellent (112). Decanal is an agent that kills fungi and antimicrobials by preventing them from growing or reproducing (Supplementary Table 2). Essential oil is used in the pharmaceutical and cosmetic industries, as well as the tobacco and food businesses, as a taste enhancer and preservative (113). It is also used in the treatment of inflammation and chronic ulcer (3). The high hydroxychavicol content of this plant makes it a desirable dietary supplement for the treatment and prevention of a variety of ailments (80). The essential oils derived from the leaves of $S$. polyanthum will be useful as antidiabetic, antioxidant, antibacterial, antifungal and as food preservative sources.

\section{Conclusion}

One of the most important sources for drug discovery is ethnomedicinal plants. S. polyanthum is an ethnomedicinal plant that is gaining popularity due to its diverse pharmacological properties. Numerous studies have been conducted on the plant parts, the majority of which have focused on the leaves. According to phytochemical studies, monoterpene, sesquiterpene, oxygenated monoterpenes, oxygenated sesquiterpenes hydrocarbons, phenolic and flavonoid compounds are responsible for the plant's medicinal activities.

Chemical profiling indicated irregularities in chemical composition, implying that the concentration contents of S. polyanthum fluctuate depending on plant location, age, collection time and processing method. As a result, a standard should be set up based on the following; geographic region, age, collection time and preparation procedure. Such efforts will lay a solid foundation for the plant's future development, modernization and clinical use, to find out which compound is responsible for these therapeutic effects of the leaves, to explore the principle of its action, a well designed clinical trial is required. It is also suggested to evolve conservation strategies of the plant in Asia to avoid extinction.

\section{Acknowledgements}

I would like to express my sincere appreciation and gratitude to my supervisory team; Professor Dr. Nashriyah Mat and Professor Abdul Manaf Ali for their support and guidance. The chief editor, sectional editor and reviewers who volunteered their time and expertise to considerably improve the quality of this work are gratefully appreciated. Also, to Razeeqa Muhammad Shafiu, Dr. Abdulnasir Isah and Usman Muhammad for English proofreading.

\section{Compliance with ethical standards}

Conflict of interest: Authors do not have any conflict of interests to declare.

Ethical issues: None.

\section{Supplementary data}

Table 1. Summary of the biological evaluation of S. polyanthum

Table 2. Chemical contents of Syzygium polyanthum

\section{References}

1. Awang NA, Ali AM, Abdulrahman MD, Mat N. Edible bitter mushroom from Besut, Malaysia. Journal of Agrobiotechnology. 2018;9(2):70-79.

2. Ramawat K, Sonie K, Sharma M. Chapter 1 Therapeutic Potential of Medicinal Plants: An Introduction, in biotechnology of medicinal plants. [e-book] 2004, CRC Press. 2004 [cited 2021 Jun 20];1532. Available from: Chapter1Therapeutic Potential of Medicinal Plants: An Introduction (taylorfrancis.com).

3. Mahmoud AD, Ali AM, Khandaker MM, Fatihah HNN, Awang NA, Mat N. Discrimination of Syzygium polyanthum Cultivars (Wight) Walp based on essential oil composition. Journal of Agrobiotechnology. 2019;10(1):1-9.

4. Karunamoorthi KK, Jegajeevanram J, Vijayalakshmi E, Mengistie A. Traditional medicinal plants: a source of phytotherapeutic modality in resource-constrained health care settings. J Evid Based Complementary Altern Med.2013;18(1):67-74. https:// doi.org/10.1177/2156587212460241.

5. Mahara AK. Use of Herbal Medicines by Traditional Healing Practitioners: A case study of Phoksundo VDC of Dolpa district in Nepal [Internet]. 2009. [cited 8 Aug 2021]. Available from: Web Filter Violation (nhrc.gov.np).

6. Uprety $\mathrm{Y}$, Asselin H, Dhakal A, Julien N. Traditional use of medicinal plants in the boreal forest of Canada: review and perspectives. J Ethnobiol Ethnomed. 2012;8(1):1-14.

7. Hamilton AC. Medicinal plants, conservation and livelihoods. Biodivers and Conserv. 2004;13(8):1477-1517.

8. Gurib FA. Medicinal plants: traditions of yesterday and drugs of tomorrow. Mol Aspects Med. 2006;27(1);1-93. https:// doi.org/10.1016/j.mam.2005.07.008.

9. Mahmoud AD, Labaran I, Yunusa A. Ethnobotany of medicinal plants with antimalarial potential in Northern Nigeria. Ethnobot Res Appl. 2020;19:1-8. https://doi.org/10.32859/era.19.32.1 -8 .

10. Jamshidi KF, Lorigooini Z, Amini KH. Medicinal plants: Past history and future perspective. J. HerbMed Pharmacol. 2018;7(1):1-9. https://doi.org/10.15171/jhp.2018.01.

11. Giannenas IE, Sidiropoulou E, Bonos E, Christaki, Florou PP. The history of herbs, medicinal and aromatic plants, and their extracts: Past, current situation and future perspectives, In: Feed Additives. 2020; Elsevier. 1-18. https://doi.org/10.1016/B978-0-12 -814700-9.00001-7.

12. Bussmann RW, Sharon D. Traditional medicinal plant use in Northern Peru: tracking two thousand years of healing culture. J Ethnobiol Ethnomed. 2006;2(1):1-18. https:// doi.org/10.1186/1746-4269-2-47.

13. Megersa M, Asfaw Z, Kelbessa E, Beyene A, Woldeab B. An ethnobotanical study of medicinal plants in Wayu Tuka district, east Welega zone of oromia regional state, West Ethiopia. J Ethnobiol Ethnomed. 2013;9(1):1-18.

14. Sumono A, Sd AW. The use of bay leaf (Eugenia polyantha Wight) in dentistry. Dent. J. 2008;41(3):147-150. https:// doi.org/10.20473/j.djmkg.v41.i3.p147-150. 
15. Ismail A, Mohamed M, Sulaiman S, Wan WA. Autonomic nervous system mediates the hypotensive effects of aqueous and residual methanolic extracts of Syzygium polyanthum (Wight) Walp. var. polyanthum leaves in anaesthetized rats. J Evid Based Complementary Altern Med. 2013. https://downloads.hindawi.com/ journals/ecam/2013/716532.pdf.

16. Mahmoud AD, Fatihah HNN, Khandaker MM, Ali AM, Mat N. Ethnobotany of Syzygium polyanthum (Wight) Walp in Terengganu, Peninsular Malaysia. Journal of Agrobiotechnology. 2020;11 (2):39-47.

17. Abdulrahman MD, Ali AM, Fatihah $\mathrm{H}$, Khandaker MM, Mat N. Traditional medicinal knowledge of Malays in Terengganu, Peninsular Malaysia. Malay. Nat. J. 2018;70(3): 349-364.

18. Kusuma IW, Kuspradini H, Arung ET, Aryani F, Min YH, Kim JS, Kim YU. Biological activity and phytochemical analysis of three Indonesian medicinal plants, Murraya koenigii, Syzygium polyanthum and Zingiber purpurea. J Acupunct. Meridian Stud. 2011;4 (1):75-79. https://doi.org/10.1016/S2005-2901(11)60010-1.

19. Ismail A, Ahmad WANW. Syzygium polyanthum (Wight) Walp: a potential phytomedicine. Pharmacogn Mag. 2019;11(2):429-38. https://doi.org/10.5530/pj.2019.11.67.

20. Dewijanti ID, Mangunwardoyo W, Dwianti A, Hanafi M, Artanti N, Mozef T, Devi AF. Antimicrobial activity of bay leaf (Syzygium polyanthum (wight) walp) extracted using various solvent. In: AIP Conference Proceedings. 2019. AIP Publishing LLC. https:// doi.org/10.1063/1.5134585.

21. Safriani N, Arpi N, Erfiza NM, Potency of curry (Muraya koeniigi) and salam (Eugenia polyantha) leaves as natural antioxidant sources. Pak J Nutr. 2015;14(3):131-35.

22. Falah S, Wahyuni WT, Tachibana S. Cellular mechanism of the cytotoxic effect of extracts from Syzygium polyanthum leaves. Am Drug Discov Dev. 2014;4(2):90-101.101. https://doi.org/10.3923/ ajdd.2014.90.101.

23. Pandey AK, Singh P. The genus Artemisia: A 2012-2017 literature review on chemical composition, antimicrobial, insecticidal and antioxidant activities of essential oils. J Med. 2017;4(3): 21510.3390/medicines4030068.

24. Widyawati T, Yusoff NA, Asmawi MZ, Ahmad M. Antihyperglycemic effect of methanol extract of Syzygium polyanthum (Wight.) leaf in streptozotocin-induced diabetic rats. Nutrients. 2015;7 (9):7764-80. https://doi.org/10.3390/nu7095365.

25. Ramadhania NR, Purnomo AS, Fatmawati S. Antibacterial activities of Syzygium polyanthum wight leaves. AIP Conference Proceedings. 2018. In: AIP Publishing LLC. https:// doi.org/10.1063/1.5082429.

26. Wijayakusuma $\mathrm{H}$, Dalimartha $\mathrm{S}$, Wirian A. Tanaman Berkhasiat Obat di Indonesia Jilid IV. Jakarta Pustaka Kartini. 1996;7(8):14856.

27. Dewijanti I, Mangunwardoyo W, Dwiranti A, Hanafi M, Artanti N. Effects of the various source areas of Indonesian bay leaves (Syzygium polyanthum) on chemical content and antidiabetic activity. Biodivers J 2020;21(3):1190-95. https:// doi.org/10.13057/biodiv/d210345.

28. Othman A, Mukhtar NJ, Ismail NS, Chang SK, Phenolics, flavonoids content and antioxidant activities of 4 Malaysian herbal plants. Int Food Res J. 2014;21(2):759-66.

29. Dewijanti ID, Artanti N, Mangunwardoyo W, Hanafi M, Abbas J, Megawati M, Minarti M, Musdalifah D, Meilawati L. Bioactivities of Syzygium polyanthum (Wight) Walp leaf extract for decreasing diabetic risk. In: AIP Conference Proceedings. 2018. In: AIP Publishing LLC. https://doi.org/10.1063/1.5064297.

30. Ahmad N. Chemical composition, antioxidant and antibacterial activity of essential oil from leaf of Syzygium polyanthum (Wight) Walp. Faculty of Industrial Sciences and Technology. PhD [dissertation]. Universiti Malaysia Pahang; 2014. Available from: 159185268.pdf (core.ac.uk).

31. Sachan A, Kumar S, Kumari K, Singh D. Medicinal uses of spices used in our traditional culture: Worldwide. J Med Plants Stud. 2018;6(3):116-22.

32. Lelono RAA, Tachibana S. Preliminary studies of Indonesian Eugenia polyantha Leaf extracts as inhibitors of key enzymes for type 2 diabetes. J Med Sci. 2013;13(2):103 -10.

33. Wijaya S. Indonesian food culture mapping: a starter contribution to promote Indonesian culinary tourism. J Ethn Foods. 2019;6(1): 1-10. https://doi.org/10.1186/s42779-019-0009-3.

34. Hidayati MD, Ersam T, Shimizu K, Fatmawati S. Antioxidant activity of Syzygium polyanthum extracts. Indones J Chem. 2017;17 (1):49-53. https://doi.org/10.22146/ijc.23545.

35. Abdulrahman MD, Ali AM, Fatihah H, Khandaker MM, Mat N, B. Morphological and anatomical studies of Syzygium polyanthum (Wight) Walp. (Myrtaceae). Mal Nat J. 2018;70(3):309-22.

36. Abdulrahman MD, Fatihah HNN, Ali M, Mat N, Khandaker M. Phenetic and unsupervised multivariate analysis Syzygium polyanthum (Wight) Walp. Iraqi J of Agric Sci. 2021;52(1): 249-58. https://doi.org/10.36103/ijas.v52i1.1255.

37. Pham GN, Nguyen TTT, Nguyen NH. Ethnopharmacology, phytochemistry and pharmacology of Syzygium nervosum. J Evid Based Complementary Altern Med. 2020. https:// doi.org/10.1155/2020/8263670.

38. Abdulrahman M. Antioxidant, alpha glucosidase and antibacterial evaluation of Syzygium mytifolium (Roxb.) Walp. Plant Science Today. 2021;8(2):410-15. https://doi.org/10.14719/ pst.2021.8.2.1113

39. Lucas E, Belsham S, Lughadha EN, Orlovich D, Sakuragui C, Chase $\mathrm{M}$, Wilson $\mathrm{P}$. Phylogenetic patterns in the fleshy-fruited Myrtaceae-preliminary molecular evidence. Plant Syst Evol. 2005;251(1):35-51. https://doi.org/10.1007/s00606-004-0164-9.

40. Lucas EJ, Harris SA, Mazine FF, Belsham SR, Nic EM, Lughadha A, Telford P, Gasson A, Chase MW. Suprageneric phylogenetics of Myrteae, the generically richest tribe in Myrtaceae (Myrtales). Taxon.2007;56(4):1105-28. https://doi.org/10.2307/25065906.

41. Grattapaglia D, Vaillancourt RE, Shepherd M, Thumma BR, Foley W, Külheim C. Potts BM, Myburg AA. Progress in Myrtaceae genetics and genomics: Eucalyptus as the pivotal genus. Tree Genet Genom. 2012:8(3):463-508. https://doi.org/10.1007/s11295-0120491-x.

42. Pennington RT, Cronk QC, Richardson JA, Introduction and synthesis: plant phylogeny and the origin of major biomes. Philosophical Transactions of the Royal Society of London. Series B: Biological Sciences. 2004;359(1450):1455-64. https:// doi.org/10.1098/rstb.2004.1539.

43. Ayyanar M, Subash BP. Syzygium cumini (L.) Skeels: A review of its phytochemical constituents and traditional uses. Pac J Trop Biomed. 2012;2(3):240-46. https://doi.org/10.1016/S2221-1691 (12)60050-1.

44. Nair KN. The genus Syzygium: Syzygium cumini and other underutilized species. CRC Press; 2017: 56-71.

45. Whistler WA, Elevitch CR, Syzygium malaccense (Malay apple). Species profiles for Pacific Island Agroforestry. 2006;2:1-13.

46. Mahmoud II, Marzouk MS, Moharram FA, El-Gindi MR, Hassan AM. Acylated flavonol glycosides from Eugenia jambolana leaves. Phytochemistry. 2001;58(8): 1239-44. https://doi.org/10.1016/ S0031-9422(01)00365-X.

47. Craven L. Studies in Papuasian Syzygium (Myrtaceae): 1. Subgenus Perikion revised. blumea-biodiversity. Evolution and Biogeography of Plants. 2019;64(2):115-22. https://doi.org/10.3767/ blumea.2019.64.02.03. 
48. Soh WK. Parnell J. A revision of Syzygium Gaertn. (Myrtaceae) in Indochina (Cambodia, Laos and Vietnam). Adansonia. 2015;37 (2):179-275. https://doi.org/10.5252/a2015n2a1.

49. Brambach FJ, Byng W, Culmsee H. Five new species of Syzygium (Myrtaceae) from Sulawesi, Indonesia. PhytoKeys. 2017;(81):4778. https://doi.org/10.3897/phytokeys.81.13488.

50. Raman VR, Bussmann W, Khan IA. Which bay leaf is in your spice rack?-A quality control study. Planta Med. 2017; 83(12/13):105867. https://doi.org/10.1055/s-0043-103963.

51. Soh WK, Parnell J. Comparative leaf anatomy and phylogeny of Syzygium Gaertn. Plant Syst Evol. 2011;297(1):1-32. https:// doi.org/10.1007/s00606-011-0495-2.

52. Syabana MA, Yuliana ND, Batubara I, Fardiaz D. Characterization of Antioxidant Compound from Syzygium polyanthum Leaves fraction using UHPLC-HRMS. Molekul. 2021;16(1):38-45. http:// dx.doi.org/10.20884/1.jm.2021.16.1.666.

53. Shahidi F, Zhong Y. Measurement of antioxidant activity. J Funct Foods. 2015;18: 757-781. https://doi.org/10.1016/ j.jff.2015.01.047.

54. Abdulrahman MD, Hasan NH, Khandaker MM, Ali AM, N. Mat N. In vitro biological investigations on Syzygium polyanthum cultivars. Int J Agric Biol. 2019;22(6):1399-1406. https://doi.org/10.17957/ IJAB/15.1214.

55. Darusman LK, Wahyuni WT, Alwi F. Acetylcholinesterase inhibition and antioxidant activity of Syzygium cumini, S. aromaticum and S. polyanthum from Indonesia. J Biol Sci. 2013;13(5):412-16.

56. Dogara A, Labaran I, Hamad SW, Lema AA, Jakada BH. Traditional medicinal plants used for the treatment of cancer in Mubi, Adamawa State, Nigeria. Al-Qadisiyah Journal of Pure Science. 2021;26(4):258-68. https://doi.org/10.29350/qjps.2021.26.4.1423.

57. Setyawati A, Hirabayashi K, Yamauchi K, Hattori H, Mitsunaga T, Batubara I, Heryanto R, Hashimoto H, Hotta M. Melanogenesis inhibitory activity of components from Salam leaf (Syzygium polyanthum) extract. J Nat Med. 2018;72(2):474-80. https:// doi.org/10.1007/s11418-018-1171-4.

58. Syabana MA, Yuliana ND, Batubara I, Fardiaz D. a-glucosidase inhibitors from Syzygium polyanthum (Wight) Walp leaves as revealed by metabolomics and in silico approaches. J Ethnopharmacol. 2021. j.jep.2021.114618.

59. Abd Rahim ENA, Ismail A, Omar MN, Rahmat UN, Ahmad WANW. GC-MS analysis of phytochemical compounds in Syzygium polyanthum leaves extracted using ultrasound-assisted method. Pharmacogn Mag. 2018;10(1):110-19. https://doi.org/10.5530/ pj.2018.1.20.

60. Arundita S, Kurniawan F, Ismed F, Rita RS, Putra DP. In vitro Alpha Glucosidase Activity of Uncaria gambir Roxb. and Syzygium polyanthum (Wight) Walp. from West Sumatra, Indonesia. Open Access Maced. J Med Sci. 2020;8(A):810-17.

61. Widyawati T, Pase MA, Daulay M, Sumantri IB. Effect of bay leaf ethanol extract on blood glucose level in patients with Type 2 Diabetes Mellitus. In. 6th International Conference on Public Health 2019. 2019. Sebelas Maret University. https:// doi.org/10.26911/the6thicph-FP.05.07.

62. Wahjuni S, Laksmiwati AM, Manuaba IBP. Antidiabetic effects of Indonesian bay leaves (Syzygium polyanthum) extracts through decreasing advanced glycation end products and blood glucose level on alloxan-induced hyperglycemic wistar rats. Asian J Pharm Clin. 2018;11(4):340-43.

63. Elya B, Handayani R, Sauriasari R, Hasyyati US, Permana IT, Permatasari YI. Antidiabetic activity and phytochemical screening of extracts from Indonesian plants by inhibition of alpha amylase, alpha glucosidase and dipeptidyl peptidase IV. Pak J Biol Sci. 2015;18(6):279-84.
64. Wahjuni S, Wita IW. Hypoglycemic and antioxidant effects of Syzygium polyanthum leaves extract on alloxan induced hyperglycemic Wistar Rats. Bali Med J. 2017;3(3): 113-16. https:// doi.org/10.15562/bmj.v3i3.755.

65. Hamad A, M. Mahardika M, Yuliani I, Hartanti D. Chemical constituents and antimicrobial activities of essential oils of Syzygium polyanthum and Syzygium aromaticum. Rasayan J Chem. 2017;10 (2):564-69. https://doi.org/10.7324/RJC.2017.1021693.

66. Ramli S, Radu S, Shaari K, Rukayadi Y. Antibacterial activity of ethanolic extract of Syzygium polyanthum L. (Salam) leaves against foodborne pathogens and application as food sanitizer. Biomed Res. Int.2017; https://doi.org/10.1155/2017/9024246.

67. Ramli S, Lim L, Samsudin N, Rukayadi Y. Effect of salam [Syzygium polyanthum (Wight) Walp.] leaves extract on the microorganism population in chicken meat and shrimp and their sensory. Int Food Res. 2018;25(3):928-35.

68. Umaru IJ, Umaru KI, Umaru HA. Phytochemical screening, isolation, characterization of bioactive and biological activity of Bungkang, (Syzygium polyanthum) root-bark essential oil. The Korean Journal of Food and Health Convergence. 2020;6(3):5-21. https://doi.org/10.13106/kjfhc.2020.vol6.no3.5.

69. Grosvenor PW, Supriono A, Gray DO, Medicinal plants from Riau Province, Sumatra, Indonesia. Part 2: antibacterial and antifungal activity. J Ethnopharmacol. 1995;45(2):97-111. https:// doi.org/10.1016/0378-8741(94)01210-Q.

70. Guynot MS, Marin LS, Sanchis V, Ramos A. Screening for antifungal activity of some essential oils against common spoilage fungi of bakery products. Food Sci Technol Int. 2005;11(1):25-32. https://doi.org/10.1177/1082013205050901.

71. Kusuma SAF, Purnamasari E, Herawati IE. Syzygium polyanthum (Wight) Walp. leaves extract as the antifungal agent for oral candidiasis. Drug Discov.2019;12(7):1339-42.

72. Ismail A, Ahmad WANW. Autonomic receptors and nitric-oxide involvements in mediating vasorelaxation effect induced by Syzygium polyanthum leaves extract. Pharmacogn Res. 2017;9 (1):9-14. https://doi.org/10.4103/pr.pr_69_17.

73. Ismail A, Ramli NS, Mohamed M, Ahmad WANW. Acute and subacute antihypertensive effects of Syzygium polyanthum leaf extracts with determination of gallic acid using HPLC analysis. Pharmacogn Mag. 2018;10(4):663-71. https://doi.org/10.5530/ pj.2018.4.109.

74. Ramli N, Muhammad N, Safuan S, Noordin L, Wan AW. Preliminary evaluation on the effect of methanolic extract from Syzygium polyanthum on improvement of hypertensive-renal damage among Spontaneous Hypertensive rat models. Ann Microsc. 2017:16:15-22.

75. Malik A. Antidiarrheal acitivity of ethanolik extract of bay leaves (Syzygium polianthum (Wight) Walp. Int Res J Pharm. 2013;4 (4):106-08. 10.7897/2230-8407.04418.

76. Wachtel MR, Charkowski AO, Cross-contamination of lettuce with Escherichia coli 0157: H7. J Food Prot. 2002;65(3):465-70. https:// doi.org/10.4315/0362-028X-65.3.465.

77. Jayaraman S, Manoharan MS, Illanchezian S. In-vitro antimicrobial and antitumor activities of Stevia rebaudiana (Asteraceae) leaf extracts. Trop J Pharm. 2008;7(4): 1143-49. 10.4314/ tjpr.v7i4.14700.

78. Mooi LY, Ali A, Norhanom A, Salleh KA. Murakami, K. Koshimizu. Anti-tumor promoting activity of some Malaysian traditional vegetables (ulam). Nat Prod Sci. 1999;5(1):33-38.

79. Alias N, Leow T, Ali M, Tajudin A, Salleh A, Rnzra R. Anti-obesity potential of selected tropical plants via pancreatic lipase inhibition. Advances in Obesity, Weight Management and Control. 2017;6(4):1-11. 
80. Kato E, Nakagomi R, Gunawan PMD, Kawabata J. Identification of hydroxychavicol and its dimers, the lipase inhibitors contained in the Indonesian spice, Eugenia polyantha. Food Chem. 2013;136(3 -4):1239-42. https://doi.org/10.1016/j.foodchem.2012.09.013.

81. Sukmawati RK, Saharuddin N. Kombinasi Ekstrak Etanol Daun Kemangi (Ocimum bacilicum L.) dan Daun Salam (Syzygium polyanthum (Wight) Walp) sebagai Antiinflamasi pada Tikus (Rattus norvegicus). Jantan yang Diinduksi Karagen. 2018; 1-10.

82. Avriliyanti F, Suparwitri S, Alhasyimi AA. Rinsing effect of $60 \%$ bay leaf (Syzygium polyanthum Wight) aqueous decoction in inhibiting the accumulation of dental plaque during fixed orthodontic treatment. Dent J. 2017;50(1):1-5. http://dx.doi.org/10.20473/ j.djmkg.v50.i1.p1-5.

83. Hasan RD, Lindarto GA, Mukhtar SZ. The effect of bay leaf extract Syzygium polyanthum (Wight) Walp. on C-reactive protein (CRP) and myeloperoxidase (MPO) level in the heart of rat model of myocardial infarction. Med Glas. 2020;17(1):1-5.

84. Hasan, R., G.A. Siregar, Lindarto D. Syzygium polyanthum Reduced TNF- $\alpha$ and ADAM17 Protein expression in myocardial infarction rat model. Med Arch Dec. 2020;74(6):416-20. https:// doi.org/10.5455/medarh.2020.74.416-420

85. Chinedu E, Arome D, Ameh FS. A new method for determining acute toxicity in animal models. Toxicol Int. 2013;20(3):24-226. https://doi.org/10.4103/0971-6580.121674.

86. Dewijanti I. Mangunwardoyo W, Artanti N, Hanafi M. Bioactivities of Salam leaf (Syzygium polyanthum (Wight) Walp). In: AIP Conference Proceedings. 2019. AIP Publishing LLC. ); https:// doi.org/10.1063/1.5132499.

87. Nordin ML, Othman AA, Kadir AA, Shaari R, Osman AY, Mohamed M. Antibacterial and cytotoxic activities of the Syzygium polyanthum leaf extract from Malaysia. Vet world. 2019;12(2):2231-916. https://doi.org/10.14202/vetworld.2019.236-242.

88. Hartanti L, Yonas SMK, Mustamu JJ, Wijaya S,. Setiawan HK, Soegianto. Influence of extraction methods of bay leaves (Syzygium polyanthum) on antioxidant and HMG-COA Reductase inhibitory activity. Heliyon. 2019;5(4):1-15. https:// doi.org/10.1016/j.heliyon.2019.e01485.

89. Perumal S, Mahmud V, Piaru SP, Cai LW, Ramanathan S. Potential antiradical activity and cytotoxicity assessment of Ziziphus mauritiana and Syzygium polyanthum. Int J Pharmacol. 2012;8 (6):535-41. https://doi.org/10.3923/ijp.2012.535.541.

90. Dono N. In vitro antibacterial activities of Syzygium polyanthum leaves extract-nanoparticle against Salmonella typhimurium, Escherchia coli and Lactobacillus acidophilus. In: IOP Conference Series: Earth and Environmental Science. 2021. IOP Publishing. : https://doi.org/10.1088/1755-1315/782/2/022093.

91. Widyawati T, Roslan N, Yusoff N, Asmawi M, Ahamad M. The evaluation of antioxidant and free radical scavenging activities of Eugenia polyantha leaves extracts. Int J Chemtech Res. 2016;9 (9):465-71.

92. Ramadhania ZM, Insanu M, Gunarti N, Wirasutisna KR, Sukrasno S, Hartati R. Antioxidant activity from ten species of Myrtaceae. Asian J Pharm Clin Res. 2017; 10(14):5;1-7. http:// dx.doi.org/10.22159/ajpcr.2017.v10s2.19470.

93. Lelono R, Tachibana S, Itoh K. In vitro antioxidative activities and polyphenol content of Eugenia polyantha Wight grown in Indonesia. Pak J Biol Sci. 2009;12(24):1564-70. https://doi.org/10.3923/ pjbs.2009.1564.1570.

94. Sandikapura MJ, Nyamathulla S, Noordin MI. Comparative antioxidant and antidiabetic effects of Syzygium polyanthum leaf and Momordica charantia fruit extracts. Pak J Pharm Sci. 2018;31:113.

95. Rahayu I, Heng $\mathrm{PH}$, Timotius $\mathrm{KH}$, In vitro antioxidant properties and a-Glucosidase inhibition of combined leaf infusions from Psidium guajava L., Syzygium polyanthum L., and Annona muri- cata L. Pharmacogn J. 2019;11(6):1269-77. https:// doi.org/10.5530/pj.2019.11.197.

96. Sukmasari S, Mohd FN, Qader OAJA, Rahman MNA. Total phenolic content, flavonoid content and antioxidant capacity of Syzygium. cumini (L.) Skeels leaves grown in Wonosobo, Java, Indonesia and comparison against current findings of Syzygium cumini leaves and Syzygium polyanthum (Wight) Walp leaves. J Pharm Sci. 2018;10(1):31-35.

97. Wong SP, Leong LP, Koh JHW. Antioxidant activities of aqueous extracts of selected plants. Food Chem. 2006;99(4):775-83. https://doi.org/10.1016/j.foodchem.2005.07.058

98. Muhammad S, Shaik N, Mohamed N. Comparative antioxidant and antidiabetic effects of Syzygium polyanthum leaf and Momordica charantia fruit extracts. Pak J Pharm Sci. 2018;31:623-35.

99. Widjajakusuma EC, Jonosewojo A, Hendriati L, Wijaya S, Surjadhana A, Sastrowardoyo W, Monita N, Muna NM, Fajarwati RP, Ervina M. Phytochemical screening and preliminary clinical trials of the aqueous extract mixture of Andrographis paniculata (Burm. f.) Wall. ex Nees and Syzygium polyanthum (Wight.) Walp leaves in metformin treated patients with type 2 diabetes. Phytomedicine. 2019;55:137-47. https://doi.org/10.1016/ j.phymed.2018.07.002.

100. Parisa N, Tamzil NS,. Harahap DH, Prasasty GD, Hidayat R, Maritska Z, Prananjaya BA. The effect of leaf Salam extracts (Syzygium polyanthum) in diabetes mellitus therapy on wistar albino rats. Journal of Physics: Conference Series. 2019. IOP Publishing. https://doi.org/10.1088/1742-6596/1246/1/012034.

101. Widharna RM, Tamayanti WD, Hendriati L, Hamid IS, Widjajakusuma EC. Antidiabetic effect of the aqueous extract mixture of Andrographis paniculata and Syzygium polyanthum leaf. European J Med Plants. 2015;82-91. https://doi.org/10.9734/ EJMP/2015/15601.

102. Berawi KN, Shidarti L, Nurdin SU, Lipoeto NI, Wahid I. Comparison effectiveness of antidiabetic activity extract herbal mixture of soursop leaves (Annona muricata), Bay leaves (Syzygium polyanthum) and Pegagan leaves (Centella asiatica). Biomed Pharmacol. 2017;10(3):1481-88. https://dx.doi.org/10.13005/bpj/1256.

103. Alwie RR, Mumpuni E, Sulastri L. Simanjuntak P, Aktivitas Ekstrak Etanol Daun Salam [Syzygium polyanthum (Wight) Walp.] Sebagai Penghambat Enzim a-Glukosidase Dan Studi Secara In Silico. Jurnal Fitofarmaka Indonesia. 2021;8(2):36-42. https:// doi.org/10.33096/jffi.v8i2.750.

104. Lau K, Zainin N, Abas F, Rukayadi Y. Antibacterial and sporicidal activity of Eugenia polyanthum Wight against Bacillus cereus and Bacillus subtilis. Int J Curr Microbiol Appl Sci. 2014;3:499-510.

105. Sri AFK, Danni R, Resmi M. Comparative study on activities of anti bacillary dysentry Shigella dysenteriae of Syzygium polyanthum and Dracaena angustifolia leaves ethanol extracts. Asian J Pharm Clin Res. 2017;10(2):348-52. http://dx.doi.org/10.22159/ ajpcr.2017.v10i2.15725.

106. Ismail A, ENAA, Rahim MN, Omar D, Ahmad WANW. Antihypertensive assay-guided fractionation of Syzygium polyanthum leaves and phenolics profile analysis using LCQTOF/MS. Pharmacogn J. 2020;12(6s):1670-92. https://doi.org/10.5530/pj.2020.12.227.

107. Prahastuti S, Tjahjani S, Hartini E. The effect of bay leaf infusion (Syzygium polyanthum (Wight) Walp to decrease blood total cholesterol level in dyslipidemia model wistar rats. Jurnal Medika Planta. 2011;1(4):27-32.

108. Ramli S, Radu S, Shaari K, Rukayadi Y. Toxicity analysis of Syzygium polyanthum (Wight) Walp. leaves extract and its stability against different $\mathrm{pH}$ and temperature. Emir J Food Agric. 2020;461-68. https://doi.org/10.9755/ejfa.2020.v32.i6.2116.

109. Jumaat SR, Tajuddin SN, Sudmoon R, Chaveerach A, Abdullah $\mathrm{UH}$, Mohamed R. Chemical constituents and toxicity screening of 
three aromatic plant species from Peninsular Malaysia. Bio Resources. 2017;12(3):5878-95.

110. Atanasov AG, Waltenberger B, Pferschy WEM, Linder T, Wawrosch C, Uhrin PV. Temml L, Wang S, Schwaiger M, Heiss EH. Discovery and resupply of pharmacologically active plantderived natural products: A review Biotechnol Adv. 2015;33 (8):1582-1614. https://doi.org/10.1016/j.biotechadv.2015.08.001.

111. Amalina AN, MY M, Ashikin AKN. Chemical composition, antioxidant and antibacterial activities of Syzygium polyanthum (Wight) Walp. essential oils. Open Conference Proceedings Journal. 2013. https://doi.org/10.2174/2210289201304010139

112. Dhakad AK, Pandey VV, Beg S, Rawat JM, Singh A. Biological, medicinal and toxicological significance of Eucalyptus leaf essential oil: a review. J Sci Food Agric. 2018;98(3):833-48. https:// doi.org/10.1002/jsfa.8600.

113. Kamatou GP, Vermaak I, Viljoen AM, Lawrence BM. Menthol: a simple monoterpene with remarkable biological properties.
Phytochemistry. 2013;96:15-25. https://doi.org/10.1016/ j.phytochem.2013.08.005.

114. Hamad A, Saputri EY, Hartanti D. The use of bay-leaf essential oil as raw chicken meat's natural preservative. MalayBio. 2010;64 (2):234-46.

115. Abdulrahman MD, Fatihah KHNN, Mat N. Discrimination of Syzygium polyanthum (Wight) Walp. Cultivars Based on ATR-FTIR Spectroscopy. Bioscience Research. 2018;15(4):3635-46.

116. National Park. Flora and Fauna Web Repository [Internet]. Singapore: [cited 2021 Nov 28]. Available from: https:// www.nparks.gov.sg/florafaunaweb/flora/3/1/3164

117. Sabandar C, Jalil W, Ahmat J N. In vitro antioxidant activity of Syzygium polyanthum (Wight) Walpers. Proceedings of pharmaceutical sciences research day; 201515 -16 April; Malaysia. 68-71. 